\title{
ACADEMIC LISTENING IN FOREIGN LANGUAGES: LEXICAL PROCESSING OF SPOKEN TEXTS IN SPECIALITY
}

Summary. The aim of the present paper is to analyze the perception of recorded spoken texts in a foreign language by undergraduate students in ESP classes. The study explores the role of the background knowledge and pragmatic information in recognizing lexical units in the stream of speech. The paper describes a case study of undergraduate students' performance in acquiring special vocabulary in ESP classes while listening to a recorded text in the field of speciality. The two main tasks of the listener in word recognition are the identification of words and activation of knowledge of the meanings of words. There are two models of comprehension processes of spoken texts: bottom-up and top-down. Top-down listening infers the meaning from contextual clues and from making links between the spoken message and various types of the knowledge of the world or the background knowledge. Listening takes place in real time, learners listen and have to comprehend what they hear immediately. There is no time to go back and review, look up for unknown words, etc. Consequently, non-native listeners with partial linguistic knowledge are in the situation that requires them to use their background knowledge in the form of schemata and scripts. The activation of the background knowledge helps to compensate for the lack of the linguistic knowledge in a foreign language that is necessary to understand the meaning of lengthy spoken texts. Language learners have to apply the previous knowledge of the world and the knowledge of the context trying to infer the meanings of words in the context. Thus in the educational settings, where a listening activity is partly de-contextualised, pre-listening activities stimulate students' knowledge of the world in the form of schemata, and they use it to infer the meaning of unknown words or words they cannot recognise in the stream of speech in a foreign language. There are three processes that account for a word in a foreign language being remembered: noticing, retrieval and generative use (Nation, 2003). "Noticing" means creating the awareness of the word, "retrieval" involves recall of the previously studied or noticed words, "generating" means a creative use of the word in different tasks. During the study the undergraduate students of Economics, Latvia University of Agriculture, participated in vocabulary knowledge tests that checked their knowledge of lexical units acquired incidentally during listening activities, which involved pre-, while- and post-listening tasks with repeated opportunities to meet the same vocabulary in the process of the listening activity. The method called the "time series design" was applied in the case study. It can be represented graphically in the following way: T1 X PT1+PT2, where "T1" is the pre-test, " $X "$ is the treatment (the recorded spoken text + exercises), PT1 is the $1^{\text {st }}$ post-test after the treatment and PT2 is the $2^{\text {nd }}$ post-test after another two weeks. The results of Post-test 1 show a noticeable increase in students' specialised vocabulary knowledge. There is a slight decrease in the knowledge of the target lexical units in Post-test 2 in comparison with Posttest 1 , but the specialised vocabulary knowledge retained was superior to the knowledge the students had before listening. Students have to compensate for insufficient phonological, 
lexical and syntactic knowledge of foreign language. The creation of the context and the activation of the background knowledge in the pre-listening stage helped students to notice the boundaries of the unknown words of the specialised vocabulary in the stream of speech, guess their meaning and later retrieve them. Consequently, in the educational environment, it is very important to pay attention to 1 ) activating the background knowledge of students, 2 ) giving information about the context of situation, 3) providing students with repeated opportunities to meet the same lexical units during the listening session to enhance the comprehension process of the spoken text in a foreign language.

Keywords: academic listening, ESP, lexical segmentation, background knowledge, context

Santrauka. Straipsnyje pateikiamo tyrimo tikslas - išanalizuoti pirmosios pakopos studentu, besimokančiu specialiosios paskirties anglu kalbos (ESP), klausomu irašu suvokimo gebejjimus. Siekiama išnagrinèti bendro pobūdžio žiniu bei pragmatinès informacijos itaką leksiniu vienetu atpažinimui klausomame tekste. Pristatoma pirmosios pakopos studentu anglu kalbos specialybès žodyno plètojimo, klausantis specialybès tematikos irašu, analizè. Žodžio atpažinimo procese besimokantysis atlieka dvi pagrindines užduotis: žodžiu identifikavimo bei žodžiu reikšmiu aktyvavimo. Egzistuoja du sakytinio teksto suvokimo modeliai: nuo detalios informacijos pereinant prie bendrojo pobūdžio informacijos (bottom-up) arba nuo bendrojo pobūdžio informacijos prie detaliosios (top-down). Taikant top-down klausymo modeli, reikšmè suvokiama iš bendro konteksto, jungiant išgirstą minti su ivairaus pobūdžio bendrojo išprusimo žiniomis ir suvokimu. Klausymo suvokimas vyksta klausymo metu, besimokantieji turi išgirsti ir tuo pačiu metu suvokti tai, ko klausomasi. Nèra galimybės grižti ir pasitikrinti arba išsiaiškinti nežinomus žodžius. Dèl šios priežasties, besimokantiesiems, turintiems ribota lingvistinę užsienio kalbos kompetencija, būtina taikyti turimas bendro pobūdžio žinias per ¡vairias schemas bei scenarijus. Bendro pobūdžio žiniu taikymas kompensuoja užsienio kalbos lingvistinès kompetencijos, reikalingos ilgu klausomu tekstu suvokimui, stoką. Besimokantieji taiko anksčiau igytas bendrąsias žinias apie konkretu konteksta, siekdami iš konteksto išsiaiškinti žodžiu reikšmes. Akademiniame kontekste, kur klausymasis yra iš dalies dekontekstualizuotas, parengiamosios veiklos stimuliuoja besimokančiuju bendro pobūdžio žinias per ¿vairias schemas, kurias jie naudoja išsiaiškinti nežinomy bei neatpažistamy žodžiu reikšmes. Trys procesai užtikrina užsienio kalbos žodžio isiminimą: pastebejimas (noticing), atkūrimas (retrieval) bei kūrybinis vartojimas (generative use) (Nation, 2003). Pirmasis procesas reiškia supratimo apie žodi igijima, antrasis yra susijęs su anksčiau išmoktu žodžiu prisiminimu, trečiasis reiškia kūrybini žodžio vartojimą ivairiose užduotyse. Tyrimo metu Latvijos žemès ūkio universiteto pirmosios pakopos ekonomikos studentai atliko žodyno plètojimo testus, kuriuose buvo vertinamos leksiniu vienetu žinios, atsitiktinai igytos, atliekant klausymo veiklas su parengiamosiomis, klausymo bei po klausymo vykdomomis užduotimis, kurios suteikia galimybę pakartotinai išgirsti tuos pačius žodžius. Taikytas time series design metodas pagal formulę T1 X PT1+PT2, kurioje "T1" reiškia parengiamaji testa, "X" atlikimą (irašytaji sakytini teksta bei pratimus), PT1 pirmaji testa po atlikimo, PT2 antraji testą praèjus dviems savaitèms. PT1 rezultatai rodo ženklu studentu specialiojo žodyno žiniu pagerejjima. Lyginant su PT1 rezultatais, PT2 rezultatai rodo nežymu mokomu leksiniu vienetu žiniu pablogèjima, tačiau studentu igytos specialiojo žodyno žinios buvo geresnès nei prieš klausymo veiklas. Studentams tenka kompensuoti nepakankamas užsienio kalbos fonetikos, leksikos bei sintaksės žinias. Konteksto kūrimas bei bendro pobūdžio žiniu aktyvavimas parengiamojoje klausymo fazejje padeda studentams atpažinti nežinomu specialiuju žodžiu ribas klausomame tekste, atspèti ju reikšmes ir vèliau juos prisiminti. Galima daryti išvada, kad akademiniame kontekste svarbu: 1) aktyvuoti studentu bendro pobūdžio žinias, 2) suteikti informacijos apie situacijos konteksta, 3) sudaryti studentams salygas pakartotinai sutikti tuos pačius leksinius vienetus klausymo veiklose tam, kad būtu pagerinamas tekstu, klausomu užsienio kalba, suvokimo procesas.

Pagrindinès sąvokos: akademinis klausymas, specialiosios paskirties anglu kalba (ESP), leksinè segmentacija, bendro pobūdžio žinios, kontekstas. 
Резюме. Цель данной статьи - проанализировать восприятие студентами устных текстов записанных на иностранном языке во время прохождения спецкурса. Исследование выясняет роль языковой подготовки и прагматической информации в распознавании лексических единиц в потоке речи. В статье описывается экспериментальное исследование эффективности освоения студентами специальной терминологии во время прослушивания аудиозаписей с текстами по специальности. Два основных задания для слушающего - это распознавание слов и активация знания их значений. Существуют две модели процессов восприятия устных текстов: дедуктивный и индуктивный. Индуктивное аудирование подразумевает выделелние смысла из контекстовых подсказок и проведения аналогий между услышанным текстом и различными типами знаний формирующих базу знаний студента. Соответственно, не носители языка с частичными лингвистическими знаниями находятся в ситуации, которая требует использования уже имеющихся знаний в форме схем и сценариев. Активация фоновых знаний помогает компенсировать недостаток лингвистических знаний инстранного языка, которые необходимы для восприятия больших объемов устной информации. Аудирование производится в режиме реального времени, студенты должны прослушать и сразу понять услышанное. Время, чтобы вернуться и пересмотреть сделанное, а так же уточнить значения незнакомых слов, не предусмотрено. Таким образом, им необходимо использовать уже имеющуюся базу знаний и знание контекста, чтобы определить значения слов в контексте. Соответственно, в образовательном контексте, где аудирование частично деконтекстуализируется, предварительные упражнения стимулируют общие знания студентов в схематической форме, и они используются для выделения смысла незнакомых или трудных для восприятия слов в потоке иностранной речи. Существуют три процесса, отвечающих за запоминание слов на иностранном языке во время прослушивания: выделение, возвращение и воспроизведение. (Nation, 2003). «Выделение» осозначает осознания или понимания слов в потоке речи, «возвращение» подразумевает вызов в памяти ранее изученных или упомянутых слов, «воспроизведение» - продуктивное использование слов в различных упражнениях. Во время исследования студенты экономики Латвийского сельскохозяйственного универстиета принимали участие в тестах на знание лексики, которые проверяли их знания слов, случайно изученных во время прослушивания аудиозаписей с заданиями на всех стадиях аудирования. Все задания подразумевали повторение определенных лексических единиц на каждом этапе. В эксперименте был использован метод "time series design". Графически данная схема может выглядеть следующим образом: Т1 X РТ1+РТ26 где Т1 - предварительный тест, X текст для аудирования и задания к нему, РT1 - первый тест по окончании прослушивания, и Т2 повторный тест через 2 недели после предыдущего. Результаты первого теста PT1 по окончании прослушивания показывают значимое расширение словарного запаса по специальности у студентов. По сравнению с результатами первого теста РТ1, в повторном тесте РТ2 наблюдается небольшое уменьшение знания лексических единиц, но знание специализированной лексики все же остается на более высоком уровне, чем до процесса аудирования. Студентам необходимо компенсировать недостающие фонологические, лексические и синтаксические знания в иностранном языке во время прослушивания аудиозаписей с текстами по специальности. Создание контекста на стадии предпрослушивания, активация фоновых знаний помогли студентам отмечать границы слов в потоке речи во время прослушивания, распознать слов и активизировать знания их значений. Соответственно, в учебной среде следует уделять особое внимание следующим моментам: 1) активация языкового фона студентов; 2) предоставление информации о ситуативном контексте; 3) предоставление студентам возможности повторения лексических единиц в рамках одной аудиосессии с целью повысить их усваиваемость на иностранном языке.

Основные понятия: Академические слушания, английский для специальных целей, лексические сегментации, фоновые знания, контекст. 


\section{Introduction}

The aim of the present paper is to analyze the perception of the texts in foreign language focusing on lexical units of the specialised vocabulary, namely, terms of economics. The study focuses on the role of the background knowledge and context in recognising lexical items in the stream of speech. The paper describes the results of a small-scale study carried out among the $1^{\text {st }}$ and $2^{\text {nd }}$ year undergraduate students at the Faculty of Economics, Latvia University of Agriculture, to examine how ESP learners perceive spoken recorded texts of their speciality field. The study was an attempt to determine if listeners succeed in recognising word boundaries and guess the meaning of unknown terms when applying top-down processing of the speech recorded for educational purposes. The object of the research is the perception (noticing, retrieval, generating) of lexical units by students in the listening process with additional pre-listening treatment. A research method of the case study is applied.

\section{Literature Review}

Listening comprehension in foreign language is a complex, active process in which the listener must discriminate between sounds, understand vocabulary and grammatical structures, interpret stress and intonation, retain and process all the information and interpret it within the specific and broader socio-cultural context of the utterance. Listeners may have different purposes and conditions in different situations, and these differences of the purpose of communication may affect the perception of speech. Listening comprehension, where listeners are unable to interact with the speaker, as in the case of listening to an audio recording, is typical of educational settings and demands researchers' attention.

Recognition of words or lexical segmentation is the grounds of the comprehension of fluent speech. One of the indicators of the word recognition is marking word boundaries. In spoken texts, words are not separated by pauses the same way as words are separated by white spaces in written texts. The pauses in natural speech occur in every 12 syllables, meaning that, unlike readers, listeners do not have regular indications of where words begin and end. The lexical stress often fulfils the role of showing word boundaries. Lexical segmentation for nonnative listeners can be hampered by the following features (Brown, 1977, Field, 2003; Rost, 2002; Ozola, 2007): 1) the lack of between-word pauses; 2) the phonological modification of words when they occur in connected speech (reduction, assimilation, elision); 3) the rhythm pattern of rapid, connected speech; 4) limited knowledge of word meanings.

For successful comprehension learners need $95 \%$ coverage of vocabulary that means one unknown word in every 20 running words (Nation, 2003). However, even this number of unknown words could cause difficulties to language learners. The density of known words against unknown words in the text should 
be: 1 in 50 words (98 \%). Rost (2002) considers that lexical segmentation is performed in the following way: learners use such clues as the first sounds of the word and the word stress, the speech is processed word by word retrospectively, i.e., holding unrecognised words in the phonological loop while subsequent cues are processed or the analysis of its acoustic structure eliminates all candidates but one in the given context. In addition, the listeners can compensate for the words, the meaning of which they do not know, by guessing from the context by means of lexical inferencing.

The listener recognises word boundaries by identifying lexical items and activating knowledge of their meanings. As a normal speaking rate has about eight words per every two-to-three second run of speech, word recognition must occur very quickly in the listening process (Brazil, 1995). There are three processes that account for a word in a foreign language being remembered: noticing, retrieval and generative use (Nation, 2003). "Noticing" means creating the awareness of the word, "retrieval" involves recall of the previously studied or noticed words; "generating" means a creative use of the word in different tasks.

Language skills are categorised as receptive or productive. Listening along with reading is a receptive skill requiring a person to receive and understand the incoming information or input, therefore language learners can listen to and understand texts at a higher level than they can produce. In the last two decades foreign language listening comprehension researchers (Anderson \& Lynch, 1991; Celce-Murcia, 2005; Cook, 1990; Field, 1999; Hedge, 2000; Ozola, 1999; Richards, 1990; Rost, 2002) have mentioned two models of comprehension processes: bottom-up and top-down. The metaphors "top" and "bottom" are used to depict the stages through which listening proceeds. In listening, the lowest level, the bottom, refers to a phonetic feature. In bottom-up processing the listeners' lexical and grammatical competence in a foreign language provides the basis for working out the meaning. At the "top", there is a general meaning of the spoken text into which new information is integrated, as it proceeds. Listeners use the background knowledge of the topic to understand the meaning of speech trying to compensate for the insufficient linguistic knowledge of the foreign language. Topdown comprehension strategies involve the knowledge called the previous knowledge or the knowledge of the world. Richards suggests that knowledge may take several forms: it may be previous knowledge about the topic, it may be situational or contextual knowledge, or it may be knowledge stored in the long-term memory in the form of schemata and scripts (Richards, 1990, p. 51). Top-down listening infers the meaning from contextual clues and from making links between the spoken message and various types of the knowledge of the world or the background knowledge. Consequently, non-native listeners with partial linguistic knowledge are in the situation that requires them to use their background knowledge in the form of schemata and scripts. The activation of the background knowledge helps to compensate for the lack of the linguistic knowledge in a foreign language that is 
necessary to understand the meaning of lengthy spoken texts. Thus in the educational settings, pre-listening activities stimulate students' knowledge of the world in the form of schemata, and they use it to infer the meaning of unknown words or words they cannot iserecognise in the stream of speech in a foreign language.

The knowledge of the situational context, i.e., the knowledge of speakers, the setting, the topic, the purpose of the spoken text and the knowledge of what has been said earlier suggest the contextual clues to the meaning of the spoken text. The situational context has various features (Brown \& Yule, 1992; Mey, 1998; Halliday, 1989; Verdonk, 2002; Cutting, 2002): 1) the characteristics of the speaker and the listener as the participants of the speech event (age, sex, education, occupation, nationality); 2) the physical and temporary setting; 3) the genre; 4) the topic of the spoken discourse; 5) mutual knowledge and beliefs, emotions, abilities and assumptions of the participants (the speaker and listener); 6) co-text; 7) knowledge of the world; 8) cultural context; 9) intertextuality.

As regards the educational settings, a listening activity is partly de-contextualised since foreign language learners as the participants have the role of an auditor or overhearer; the listeners are informed about the genre and topic of the discourse in the task conditions but they are not aware of the place and time of the speech event, therefore the listeners are supposed to work them out while listening to the discourse or after the event. The speaker and the listeners do not have mutual knowledge and culture knowledge as they are strangers representing two different cultures. On the other hand, the co-text limits the range of possible interpretations, and the listeners can use the knowledge from the associations with similar audio/video programmes.

Many expressions are linguistically ambiguous, thus often resulting in various misunderstandings. The listener must determine which one of the possible meanings of a lexical item is the one that the speaker intends in the specific occasion. To overcome ambiguity, the listener presumes the speaker's remarks to be contextually appropriate. Linguistic communication works because the speaker and the listener share a system of inferential strategies leading the listener to iserecognise the speaker's communicative intention. Participants in any interaction pay attention only to information which seems relevant to them as regards their purpose or needs.

\section{Research methods and materials}

The study investigates the perception (noticing, retrieval, generating) of the lexical units of specialised by undergraduate students of Economics during listening sessions with additional pre-listening treatment.

The case study has been used as a research method. A method called the "time series design" suggested by Hatch and Farhady (1982, p. 25) was applied as well. It can be represented graphically in the following way $\mathrm{T} 1+\mathrm{X}$ (Pre-listening + 
Audio recording + Tasks) PT1+PT2, where "T1" is the pre-test, " $\mathrm{X}$ " is the treatment carried out in the classroom, PT1 is the $1^{\text {st }}$ post-test after the treatment and PT2 is the $2^{\text {nd }}$ post-test after another two weeks. After the pre-test (in this case, two weeks) the treatment (the listening session) was implemented and it was followed by the $1^{\text {st }}$ post test (further: Post-test 1 ). After a certain period of time (two weeks) the $2^{\text {nd }}$ post test (further: Post-test 2 ) was carried out to see the effectiveness/ineffectiveness of the applied treatment.

Participants. Seventy $1^{\text {st }}$ and $2^{\text {nd }}$ year undergraduate students of Economics, Latvia University of Agriculture, who learned English for Specific Purposes, participated in the case study. The age range was from 19 to 20. The English language was their foreign language, the level - intermediate.

Characteristics of the text. The title of the text was "UK Culture - What's a University Education Worth?" in the form of the podcast file (www.britishcouncil. org/learnenglish), the theme of it was related to the financial aspects of studying at a university in the UK. The audio recording was selected according to the following criteria: a monologue, "information report" text type, up-to-date information. The text contained 590 words, including many terms of economics. The spoken text was categorised by the author as planned, non-collaborative, scripted monologue (no marked pauses, backchanneling, hesitations, repetitions, elliptical sentences). Sixteen target lexical units from the field of economics were selected after the pilot testing from the audio transcript for the analysis.

The preparation and the implementation of the case study as well as the calculation of the results required several stages. They were the following:

Stage 1. Seventy $(n=70)$ undergraduate students of Economics (Latvia University of Agriculture) of 4 different groups were chosen to take part in the case study.

Stage 2. The audio recording "UK Culture - What's a university education worth?" in the form of a podcast (length: 3 minutes, 19 seconds) from the British Council website www.britishcouncil.org/learnenglish appropriate for the students' proficiency level was selected.

Stage 3. The pre-, while- and post- listening tasks were designed by the author for the audio recording to include additional information about the situational context. In addition, the tasks connected with the audio material were meant to draw the students' attention to the target lexical units from the field of economics.

Stage 4. 24 terms of economics were selected for the pilot-testing that was carried out with another group of students who did not participate in the case study. The aim was to identify which words are unknown to the students. Afterwards 16 lexical units were chosen which had the least level of familiarity among the pilot-test students.

Stage 5. The case study consisted of three phases (see Table 1).

Stage 6. Statistical data from the tests were analysed and summarised. 
Table 1.

Phases of the case study

\begin{tabular}{|l|l|l|}
\hline \multicolumn{1}{|c|}{ Phase 1 } & \multicolumn{1}{|c|}{ Phase 2 } & \multicolumn{1}{c|}{ Phase 3 } \\
\hline Two weeks before the actual pro- & Two weeks later the students were & Two weeks \\
cedure, the participants were giv- & exposed to an audio recording. After & later the \\
en a test to check their knowledge & the completion of the actual listen- & participants \\
of the sixteen selected terms. The & ing session (the pre-listening tasks, & were asked to \\
students did not see the written & the listening session, and the post- & do Post-test 2 \\
form of the terms, they had to & listening discussion), the participants & (the same 16 \\
listen, write down the words and & were asked to do the Post-test 1 (the & terms). \\
give the translation. & same 16 terms as two weeks ago). & \\
\hline
\end{tabular}

\section{Results and Discussion}

The pre-test was done two weeks before the actual listening session to check how many of the 16 selected terms the students already knew. Fig. 1 shows two graphs where numbers on the horizontal axis denote the selected sixteen terms of economics, one number for each term. They reflect the results of the tests of the lexical units (checking the participants' knowledge of the 16 selected terms) carried out three times during the study. The pre-test was implemented two weeks before the actual listening session. The graph of the pre-test represents the number of lexical units the participants in average knew before the listening session. Thus the participants knew on average $17.3 \%$ of all the selected lexical units. Two weeks later, the same seventy $(n=70)$ students were exposed to the treatment with the pre-listening tasks, the audio recording and the post-listening tasks after which the students were given Post-test 1 . The results of Post-test 1 show (Figure 1) a noticeable increase in students' specialised vocabulary knowledge in comparison with the pre-test. The majority knew on average $47.6 \%$ of the selected lexical units. It should be noted that various tasks did not involve the translation of the terms in the native language of the participants.

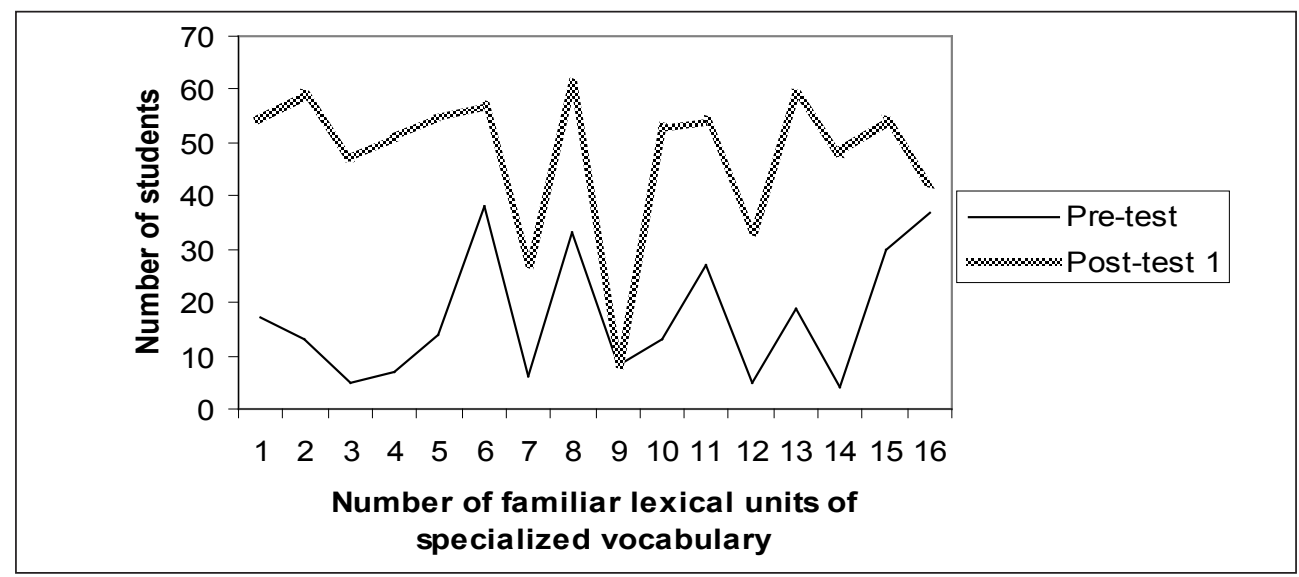

Fig. 1. Results of Pre-test and Post-test 1. 
Two weeks after the treatment and collecting of the data, the students were asked to do the same test (Post-test 2 ) once again. Its aim was to find out if the applied treatment with the listening session and tasks has been effective in retrieval of the target lexical units after a longer period of time. The statistical data acquired from Post-test 2 show the number of lexical units the students remembered after two weeks. Accordingly, the participants knew on average $42.7 \%$ of all of the selected 16 lexical units, even though some of the terms were known by almost 60 students (e.g., poverty), but some terms were known only by as many as 10 students (e.g., credit crunch).

All the results of Pre-test, Post-test 1 and Post-test 2 are compared in Figure 2. The results of both tests: Post-test 1 and Post-test 2 are obviously better than the results of Pre-test. The results of Post-test 2 are lower than the ones of Post-test 1; however, such results were foreseeable as the students' memory cannot keep all of the lexical units for two weeks. Students may remember terms for a short period of time but later meet with difficulties in retrieving them from the long-term memory. If the link that has been created in memory between the word heard in the spoken text and its lexical representation, but the mental image of it is not strong enough, the student will most likely fail to remember it. During all of the phases of the case study the students were exposed to the target lexical units at least five times (Pre-test + pre-listening tasks + an audio recording + post-listening tasks + Post-test1 + Post-test 2).

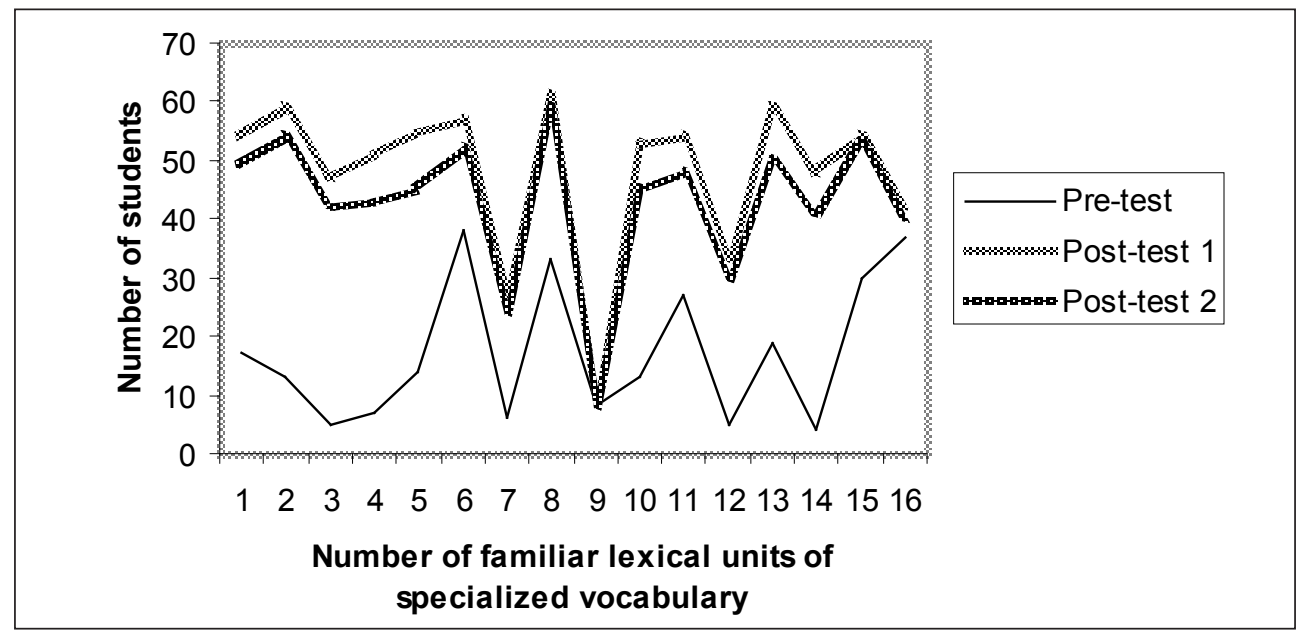

Figure 2. Comparison of Pre-, Post-test 1 and Post-test 2 results.

Language learners have to compensate for insufficient phonological, lexical and syntactic knowledge of a foreign language. Listening happens in real time, learners listen and have to comprehend what they hear immediately. There is no time to go 
back and review, look up for unknown words, etc. Thus they have to apply the previous knowledge of the world and the knowledge of the context trying to infer the meanings of words in the context. In this case pre-listening activities were aimed at creating the situational context and activating the background knowledge. The findings of the case-study prove the significance of different levels of knowledge in the perception of spoken texts. In applying this prior knowledge about the world, people and events to a particular situation, comprehension proceeds from top down if the knowledge is activated in the pre-listening stage. When listening, students confirm their expectations. Students get a better chance to notice the boundaries of lexical units and guess their meaning in the flow of speech in a foreign language.

\section{Conclusions}

The findings of the present study show that the activation of the background knowledge of the listeners and added information about the situational context in the pre-listening stage facilitate the processing of the spoken text in a foreign language, assisting in recognising word boundaries in the fluent speech and inferring the meaning of lexical items of specialised vocabulary from the context.

The results of Post-test 1 show a noticeable increase in students' specialised vocabulary knowledge. There is a slight decrease in the knowledge of the target lexical units in Post-test 2 in comparison with Post-test 1, but the specialised vocabulary knowledge retained was superior to the knowledge the students had before listening.

The present research points to the implications that the pre-listening stage is an important part of the listening session in educational settings. Learners need pre-listening activities that prepare them for the listening task. In the learning process it is very important to pay atttention to: 1 ) activation of the background knowledge; 2) provision of information about the situational context; 3) design of vocabulary exercises that practice lexical units and terms included in spoken texts.

\section{References}

Anderson, A., \& Lynch, T. (1991). Listening. Oxford University Press.

Brazil, D. (1995). A grammar of speech. Oxford, UK: Oxford University Press.

British Council Learn English. (2011). Retrieved from www.britishcouncil.org/ learnenglish.

Brown, G. (1977). Listening to spoken English. Longman.

Brown, G., \& Yule, G. (1983). Discourse analysis. Cambridge University Press.

Celce-Murcia, M., \& Olshtain, E. (2005). Discourse-based approaches: A new framework for second language teaching and learning. In E. Hinkel (ed.) Handbook of research in second language teaching and learning. London: Lawrence Erlbaum Associates. 
Cook, G. (1990). Discourse. Oxford: University Press.

Cutting, J. (2002). Pragmatics and discourse. Routledge.

Field, J. (1999). Key concepts in ELT. ELT Journal, 53(4), 338-339. Oxford: Oxford University Press.

Field, J. (2003). Promoting perception: Lexical segmentation in L2 listening. ELT Journal, 57(4). Oxford: Oxford University Press.

Halliday, A. K. (1989). Context of situation. In M. A.K. Halliday and H. Ruqaiya (Eds.). Language, context, and text: Aspects of language in a social-semiotic perspective (pp. 3-14). Oxford: Oxford University Press.

Hatch, E., \& Farhady, H. (1982). Research design and statistics for applied linguistics. Newbury: House Publishers.

Hedge, T. (2000). Teaching and learning in the language classroom. Oxford: Oxford University Press.

Levinson, S. C. (1983). Pragmatics. Oxford: Oxford University Press.

Mey, J. L. (1998). Pragmatics. Blackwell.

Nation, I. S. P. (2003). Learning vocabulary in another language. Cambridge: Cambridge University Press.

Ozola, I. (1999). The use of top-down processes in developing listening skills to the intermediate adult students. Latvijas universitātes zinātniskie raksti, 622, 30-37.

Ozola, I. (2007). Linguistic and pragmatic preconditions to processing spoken discourse in a foreign language. Riga: University of Latvia.

Richards, J. C. (1990). The language teaching matrix. Cambridge: Cambridge University Press.

Rost, M. (1993). Listening in language learning. Longman.

Rost, M. (2002). Teaching and researching listening. Pearson Education.

Verdonk, P. (2002). Stylistics. Oxford: Oxford University Press.

\section{Inese OZOLA \\ Dr. of Philology, docent}

Fields of scientific interests: applied inguistics, teaching/learning foreign languages

Latvia University of Agriculture, Language Department

Liela street 2, Jelgava, LV 3001,

Latvia

inese.ozola@llu.Iv.

\section{Inese OZOLA}

Filologijos mokslo daktarè, docentè

Moksliniu interesy sritys:

taikomoji kalbotyra, užsienio kalbu

mokymas/-is

Latvijos žemès ūkio universitetas,

Kalbu katedra

Liela g. 2, Jelgava, LV 3001,

Latvija

inese.ozola@llu.Iv. 